\title{
Class Structure and Ethics in Shinjū Ten no Amijima
}

\author{
Motoko Tanaka ${ }^{1}$ \\ ${ }^{1}$ Miyazaki Sangyo-keiei University, Japan \\ Correspondence: Motoko Tanaka, Miyazaki Sangyo-keiei University, Japan. E-mail: \\ m-tanaka@po.miyasankei-u.ac.jp
}

Received: June 27, 2015 Accepted: July 14, 2015 Online Published: August 17, 2015

doi:10.5539/ach.v8n1p28 URL: http://dx.doi.org/10.5539/ach.v8n1p28

\begin{abstract}
In Chikamatsu's sewamono genre, there are very complex social and ethical structures which derive from differences of status within the social structure. It is abundantly clear that jōruri plays depict the merchants' indirect defiance of the military class, but the people who fell below the four-class structure - like eta/hinin -also suffer from their contradictory roles in society. Both merchants and eta/hinin were indispensable to the ruling class, yet their roles were despised and they were excluded from political power. The social structure was inherently unequal, but at the same time there were contradictions and conflicts within social classes as well. Chikamatsu's masterpiece Shinjü Ten no Amijima reflects complex social and ethical conflicts within the merchant class: all the characters are bound not in a simple dichotomy between giri and ninjō but in conflicting and overlapping obligations of giri, on, jō and ichibun. Shinjū Ten no Amijima succeeds in depicting the rich humanity of the merchant class by illustrating its ethics of obligation, human relations, sympathy, and pride.
\end{abstract}

Keywords: jōruri, Chikamatsu, class structure in the Edo period, morality, Ten no Amijima

\section{Introduction}

The famous Edo jōruri (Note 1) playwright Chikamatsu Monzaemon's shinjū (love suicide) genre invites many interpretations of its extraordinary tragic endings. Many scholars interpret these endings according to politics, philosophy, religion, and ethics (Heine, 1994, p.382). Most of these approaches employ dichotomies such as the

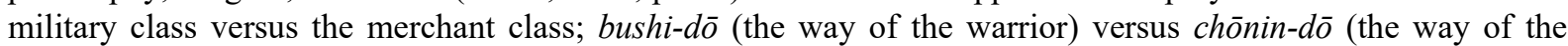
merchant); Confucianism versus Buddhism; or giri (social duty) versus ninjō (human passion). However, as Brett de Bary (1993, p.63) suggests in her article on the film Shinjū Ten no Amijima (Love Suicides at Amijima), the script is structured in a more complicated way which reflects Chikamatsu's era and his jōruri audience.

In this paper, I focus on the way in which multiple relationships in the social and ethical discourses of the Edo era influence Shinjü Ten no Amijima. First, I examine the complexity of the class system during the period, attending to the merchant class's relationship not only with the military class, but also with the lowest classes, including jōruri performers (de Bary, 1993, p.66). I underscore the importance of discerning the heterogeneity to be found within individual classes - the difference, for example, between mainstream, wealthy successful merchants and less successful merchants - as well as the difference between housewives and prostitutes (Heine, 1994, p.379).

Then I move onto the ethics that were nourished by the merchant class system. The dichotomy between giri versus ninjō has been considered the main cause for the lovers' desperate and tragic end in Shinjū Ten no Amijima, but in fact, in Chikamatsu's plays social obligation can be divided into three different types: giri, on and ichibun (Moriyama, 1960, p.216). These three different modes, along with $j \bar{o}$ - that is, sympathy - create the complexity and tension in Shinjū Ten no Amijima. Finally, I comment on the possibility of understanding whether this shinjū genre challenged the ruling class.

\section{Discussion}

\subsection{The Complexity of the Social Structure in the Edo Period}

It is well established among scholars that there was a distinctive class difference between the military class and the merchant class in the Edo period. Chikamatsu began his career in the Genroku period (1688-1703), approximately one hundred years after the establishment of the Tokugawa bakufu (government). During this period, the merchant class flourished under a government that strongly promoted commerce. However, in the Edo class system, the farmers and the craftsmen who actually produced goods were seen as superior to the merchants, who merely sold 
them. The military class believed that the merchants were of inferior intelligence: that they should be treated like children (Shively, 1955, p.338). Despite the fact that the merchants were more economically powerful than the samurai, they did not enjoy the power and prestige of the ruling class.

With money to spend but little status, the merchants turned to the pleasure quarters and the theaters, which became a "perpetual anti-structure coexisting with the mainstream social structure in a way that represented the antithesis and rejection" of the ruling class discourse (Heine, 1994, p.373). In in his close study of the struggle between bakufu and kabuki, Donald Shively suggests that the theater was an irritant to the Tokugawa bakufu, since it obviously challenged the social and moral discourse espoused by the ruling class. Since kabuki and jōruri were taken as inferior to $n \bar{o}$ drama, which justifies the ruling class discourse, they became exclusive entertainment for the townspeople (Shively, 1955, p.346).

Accordingly, kabuki and jōruri reflected merchant-class discourse. We can see several examples of the conflict between the military class and the merchant class in Chikamatsu's jōruri scripts. In Shinjū Ten no Amijima, when the rich merchant Tahei, the rival of Koharu's lover Jihei, notices that a samurai has been visiting her, Tahei dares to talk to him about how the merchant is different from the samurai:

A customer's a customer, whether he's a samurai, or a townsman. The only difference is that one wears swords and the other doesn't. But even if this samurai wears his swords he won't have five or six - there'll only be two, the broadsword and dirk... Koharu, I'm a townsman. I've never worn a sword, but I've lots of New Silver at my place, and I think that the glint could twist a mere couple of swords out of joint. (Keene, 1961, pp.175-176)

This statement illustrates that successful merchant Tahei believes that the difference between a samurai and a merchant comes down to who is permitted to wear swords. For Tahei, there should be no distinction between customers in a place like the pleasure quarter, where people use not honor or status but currency to obtain service.

Additionally, we see that Tahei measures material objects in quantitative terms: the number of swords the samurai can usually wear is two; in comparison, Tahei possesses overwhelming amounts of money which, he believes, enables him to buy whatever he wants. He even implies that the economic might of the merchant is a threat to the immeasurable honor of the military class. We cannot take Tahei's observation too seriously since the class system was unassailable at that historical juncture, but his words nonetheless reflect a naked hostility towards the ruling class who relied on the feudal system. The merchant class, as Moriyama Shigeo argues, understood reality in a more pragmatic way since it belonged to the very early mode of capitalism (Moriyama, 1960, p.217).

Another famous example of political satire in Chikamatsu's plays is Sagami Nyūdō Senbiki Inu (The Sagami Lay Monk and the Thousand Dogs). The bakufu disapproved of undesirable political commentary, and in 1644 banned the use of the names of living people in plays. Playwrights responded by changing all contemporary names and settings and recasting them in the past. For example, Chikamatsu uses the monk in the play to satirize Tokugawa Tsunayoshi (1646-1709) and his foolish legislation protecting dogs and other animals (Shively, 1955, pp.351-352).

Thus it is readily apparent that kabuki and jōruri plays are based on merchant discourse and reflect the merchants' resistance to the ruling class, an expression of dissatisfaction through the medium of performance. However, we should not forget that kabuki and jöruri plays also had as one of their central concerns the conflict between the military and the merchant classes. There are in fact three different class issues highlighted in Chikamatsu's plays.

The first issue is the relationship between the merchant class and the outcastes (Note 2). In his essay "Kurogo no Hassō" (The idea of kurogo), Shinoda Masahiro (1970, pp.209-211), who directed a film adaptation of Shinjū Ten no Amijima, argues that this lowest category played an important role in the performing arts during the Edo period. Indeed, it is crucial to remember that poor, marginal people had been engaged in the performing arts in Japan since the ancient period. These people were called eta or hinin; eta means someone who is spiritually impure, while hinin literally means non-human. These groups were regarded as supernatural figures, since they were thought to transcend reality and to know a great deal about human nature, including its negative or even evil sides. In addition to this shamanistic role, as de Bary points out, they acted as purifiers. De Bary (1993, p.66) refers to Hirota Masaki's study of eta and hinin in the Edo period:

The eta and hinin who were rigidly excluded from the four-class system nevertheless performed roles that fundamentally "supported the social order by eliminating and managing what government authorities and society viewed as 'criminal', 'heretical', and polluting."' Thus in Edo social life "they were assigned a role that was indispensable, yet which their contemporaries despised and found offensive." 
Hirota shows how eta and hinin people were manipulated by the government and were forced to bear the deep contradiction of their important but despised role of cleansing social evil by sacrificing themselves. Consequently, this contradictory role instilled in these marginal people a deep sense of hatred of and despair over the unequal power structure. This implies that the tradition of the performing arts in Japan was founded upon an anti-social structure which reflected eta/hinin people's antagonism towards the mainstream and despair of absolute alienation from power.

Chikamatsu, who was born into the military class, fell to this lowest category when he started his career as a playwright. Shinoda (1970, p.214) argues that Chikamatsu had antagonism not only toward the ruling class but also toward commoners who fit into the four-class system. However, while eta/hinin people were outside the four-class structure, it does not follow that Chikamatsu himself felt strongly antagonistic towards the merchant class. Rather, it can be understood that Chikamatsu sensed some similarities between the merchant class and the eta/hinin. The merchants, as we have seen, became very economically powerful. Yet, while the bakufu relied on their economic might, the merchants themselves had little political power. The bakufu despised the way in which they earned their living, but nevertheless recognized that the merchants' money was indispensable to the bakufu's politics. Like eta/hinin, the merchants had a fixed position in society. Frustrated by this contradiction, the merchant class became increasingly alienated during the Genroku period.

Chikamatsu saw the similarities between the despair of the outcastes and that of the merchant class, and he wrote many shinjū stories which represent the double despair of merchant class and performers. Chikamatsu's shinjū genre, therefore, is based not only on the conflict between the ruling class and the merchant class, but also on that between the rulers, the ruled, and those in the lowest social category, as well as on the similarity between the alienated merchant class in the Genroku period and the performers.

Let us turn now to an examination of the more subtle social issues within classes: the varying status of merchant women. In Chikamatsu's sewamono genre there are two types of female protagonist: the ordinary housewife and the prostitute. To categorize prostitutes within the class system is very difficult: as symbolic slaves, prostitutes played a role similar to that of the eta/hinin people. On the other hand, they were allowed to live in town, and they engaged in providing services and entertainment. In this sense, prostitutes seem to fit in the merchant class. However, prostitutes were under the strict control of the government and their employers, making them marginal members of the merchant class at best. On the other hand, although housewives in the Edo period had more freedom than prostitutes, all wives were regarded as the property of their husbands (Saeki, 1987, pp. 177-200).

According to Suwa Haruo (1974, p.327), three shinjū plays deal with the love suicides of merchant-class husbands and wives: Uzuki no Momiji (Red Leaves in April), Uzuki no Iroage (Readying in April), and Shinjū Yoigōshin (Love Suicides in the Eve of the Kōshin Festival). Also, adultery plays such as Horikawa Nami no Tsuzumi (The Dawn of the Waves of Horikawa) and Daikyoji Mukashi Goyomi (The Almanac Maker) deal with the love affairs of ordinary housewives (Saeki, 1987, pp.177-200). In Uzuki no Momiji and Uzuki no Iroage, Yohei and Kame must commit double suicide since the husband, Yohei, has a vexed relationship with his father and mother-in-law. There is no particular reason why his wife Kame should die, and, ironically, Yohei is saved by a passer-by (Torigoe, 1975a, p.194). In Shinjū Yoigōshin, the couple Hanbei and Chiyo commit suicide because Chiyo's mother-in-law has expelled her from their house (Torigoe, 1975b, p.574). In Daikyoji Mukashi Goyomi, the wife, Osan, commits adultery accidentally, having mistaken a man named Mohei for her husband in a dark room. The accidental adulterers are arrested and executed at the play's conclusion (Torigoe, 1975b, p.206). In Horikawa Nami no Tsuzumi, a woman named Tane also commits adultery, even though she loves her husband; he kills her in retaliation (Torigoe, 1975a, p.574).

These plays demonstrate the ways in which a housewife in the Edo period was expected to obey all the Confucian rules introduced by the ruling class. Women were also required to be submissive to their husbands and their husband's families in order to avoid divorce. As we have seen-except in Uzuki no Momiji and Uzuki no Iroage, in which the reasons for the suicides are ambiguous - in Chikamatsu's plays wives typically die for exactly these reasons: failure to observe Confucian moral codes such as chastity and filial piety, or failure to obey their husbands or their in-laws. Saeki Junko (1987, pp.200-205) points out that the main reason for the suicides of Chikamatsu's merchant class housewives is not adulterous love but rather a lack of loyalty to the Confucian codes which regulate wives while justifying the power of the patriarch. Indeed, Confucian law and the patriarchal system prohibited married women from being sexually attractive. Once they married, they were expected to be good wives, mothers, and daughters-in-law. They were not treated as independent women who were sexually available to other men, although husbands could have as many lovers — both female and young male — as they wished. 
In contrast, prostitutes have clearer and more dramatic reasons to wish to die, since it would have been extremely difficult for them to live with the men they deeply loved. Prostitutes in the Edo period, unlike housewives, were public figures. Their work in the pleasure quarters required courtesans to be sexually available, without regard to their feelings. If a man wanted exclusive access to a prostitute, he was forced to pay a very large sum of money to her employer. If the amount was beyond the man's means, there was no hope for the couple to be together (Saeki, 1987, pp.187-191). In Chikamatsu's Sonezaki Shinjū (Love Suicides at Sonezaki), Tokubei cannot afford to purchase the contract of the courtesan Ohatsu (Torigoe, 1975a, p.56), and in his Meido no Hikyaku (Courier for Hell) Chūbei cannot pay for the courtesan Umekawa (Torigoe, 1975b, p.28). Indeed, most of Chikamatsu's love suicide plays dealing with prostitutes are concerned with whether or not the "public" prostitute can be "privatized."

Hence, we must attend to the fact that, as in Edo society, in Chikamatsu's plays there is an unnatural division of female roles: housewives belong to the domestic sphere, they are regarded as the private property of the husband and his family, and they must bear children; while prostitutes belong to the public, erotic sphere, they must always be available, and they must not bear children.

Shinjū Ten no Amijima is the best example of a play which demonstrates this distinction. In the play Osan is an ideal wife, mother, and daughter who conforms to the Confucian and patriarchal codes. But she is not sexually attractive to her husband Jihei. Meanwhile, the courtesan Koharu is a sexual figure not only for Jihei but also for her other customers. Jihei, though grateful to his wife, cannot stop pursuing Koharu. His egoism makes both women to suffer, albeit for different reasons. Osan suffers because her husband does not love her, despite the fact that she does everything expected of her. Koharu, on the other hand, suffers because her love for Jihei violates the rules of the courtesan.

Of course, the ultimate source of the women's suffering is the same: the androcentric and feudal social structure. The Confucian ethics and the patriarchal codes impose vastly different yet identically restrictive roles upon the women; the private, domestic wife, and the public, erotic prostitute; ironically, they are equally unfree. One of the roots of tragedy in Chikamatsu's plays is this contradiction.

The third issue regarding the social structure in Edo period is the difference in status among people within the same class. According to Heine, in most of Chikamatsu's shinjū genre his male protagonists are either from the lowest rank in the hierarchy of the merchant class or are unsuccessful in their business, and are unable, therefore, to buy their lovers' contracts. In contrast are the successful merchants, such as Kuheiji in Sonezaki Shinju $\bar{u}$ and Tahei in Shinjü Ten no Amijima, who flaunt their wealth over others, including the samurai. Heine argues that we need to "distinguish between the aspirations of successful merchants and the disillusionment of the outcast townsmen Chikamatsu portrays" in addition to the larger distinction between the military class and the merchant class. Following Shively, Heine explains that loss of funds placed merchants in a doubly precarious situation: unable to survive in the "anti-structure" opposed to the ruling class, but also unable to maintain the "establishment structure" of the traditional merchant class (1994, pp.373-379). Thus, there is a clear difference between those who have money and those who do not. The wealthy merchant can stand in the way of the unsuccessful merchant's love affair by wielding his economic power.

However, Heine's argument verges on the simplistic and, in some cases, is not quite correct. First, it is misguided to consider villains like Tahei and Kuheiji as emblematic of the merchant class. As many scholars stress, the mainstream of the merchant class were the successful merchants who strove to conduct their business fairly and honestly and who used their money for the benefit of their shops and families. Nakata Yoshinao (1955, pp.34-35) explains that merchants in Edo period had their own ways or principles, as did the military class: to abstain from wasting money and to trade fairly. They tried to fulfill their contracts on time, and despised theft and unfairness. The money they made was itself regarded as a kind of god, since it showed their honesty.

This principle is well described in the Chikamatsu's sewamono play Nebiki no Kadomatsu (The Uprooted Pine) in which rich merchant Jōkan refuses to pay his son's bail. He explains the reason to his daughter-in-law's father, a samurai:

A samurai's child is reared by samurai parents and becomes a samurai himself because they teach him the warrior's code. A merchant's child is reared by merchant parents and becomes a merchant because they teach him the ways of commerce. ... Until I die, I am bound to respect my gold and silver like the gods or Buddha himself - that is the way prescribed by Heaven for merchants. Supposing I gave still more money to that rogue, lavished it on him, even after he's been punished for his wicked extravagance. What a dreadful punishment, what disasters would he then encounter! The more affectionately I think of him, the harder I find it to give him the money. (Keene, 1961, pp.151-152) 
This statement represents the way in which merchants' principles differed from those of the samurai. As money signifies their morality and honesty, the merchants work hard to earn it and to save it, and this principle promoted the development of business in the Edo period. Villains like Kuheiji and Tahei are obviously opposed to these basic principles, and therefore they cannot be regarded as representative of the successful merchant. Heine, moreover, regards Kuheiji and Tahei as equally rich. However, we cannot tell from the script whether or not Kuheiji is as wealthy as Tahei.

Secondly, and more importantly, it is true that there are conflicts between villains and unsuccessful merchants in Chikamatsu's plays, but this is not the only problem within merchant class discourse. Patriarchal figures - employers, fathers or other relatives - are often the cause of conflict. According to Nakata, the mainstream of the merchant class is most often represented by the patriarchal figure in the play, who thinks highly of thrift, honesty, and class-consciousness. Villains, on the other hand, are not always well off, and they are completely opposed to the merchant's principles. The villains flaunt the power of money, and do not feel guilty when they deceive or mock people. They are transgressors of the merchants' principles, and are regarded as outlaws by other merchants (Nakata, 1955, p.36).

How, then, do these two figures - the mainstream patriarchal merchant and the outlaw villain - conflict with the protagonist, who is an unsuccessful merchant? First, the villain and the unsuccessful merchant espouse completely different values. Both are transgressors of the merchant principles, since the lovesick merchant squanders his money to see his lover in the pleasure quarters. The crucial difference is that, while the protagonist merchant genuinely believes in love, the villain believes only in money. Tahei in Shinjü Ten no Amijima interferes with the protagonist using his economic power. Tahei dares to say to Koharu, "If I pushed with all the strength of my money, who knows what I might conquer?" (Keene, 1961, p.175) He believes that money enables him to do anything. Kuheiji in Sonezaki Shinjū and Zenjirō in Shinjū Nimaie Zōshi (Love Suicides and Double-folded Picture Books) do not actively interfere with the protagonists' love affairs, yet their deceitful belief that they can do anything for money lead to the protagonists' ruin (Torigoe, 1975a, p.56, 156). Thus, money (or the lack of money) is the root of the conflict between the villain and the unsuccessful merchant, and moreover it is a rather hostile confrontation, since the villains' intentions are usually malicious.

On the other hand, patriarchal figures can also cause problems for the unsuccessful merchants. These problems, however, are not like the conflicts brought about by the villains, who intend to do evil to the protagonists. The patriarchs, instead, constrain the protagonists, who temporally deviate from their merchant principles. The patriarchs act on behalf of the protagonists in the spirit of good will. They want the lovesick, misguided protagonists to return to their normal lives and find success in business. In Sonezaki Shinjü, the protagonist Tokubei's employer, who is also his uncle, arranges for Tokubei to marry his niece because he wants Tokubei to take over the business (Torigoe, 1975a, pp.63-66). In Ikudama Shinjū (Love Suicides at Ikudama) Gohei threatens to commit suicide if his son does not marry the woman he has chosen for him, for he is worried about his son's future (Torigoe, 1975b, pp.289-294). In Shinjū Ten no Amijima Jihei's brother and aunt interfere with his love affair because they are worried about his wife and children, and they want Jihei to work hard to maintain their traditional paper shop (Torigoe, 1975b, pp.483-486).

The conflict between patriarchal figure and unsuccessful merchant lies in whether the latter can observe the former's principles. But because the actions of the patriarchal figure toward the protagonist derive from good will it is not a hostile conflict. For the protagonists, though, it is very difficult to make an open show of defiance toward these patriarchal figures: the protagonists, after all, cannot maintain their standard of living without the patriarchs' patronage. Hence, the protagonist is faced with two different conflicts: with the villain and with the patriarch. Indeed, the protagonist is subject to triple oppression: political oppression by the ruling class, moral oppression by the patriarchal figure, and economic oppression by the villain.

As we have seen, the social structure of the Edo period caused complex conflicts. In the context of Chikamatsu's plays, the important ones are: conflict between the politically powerful military class and the economically powerful merchant class; conflict between the high-status ruling class and the extremely low status eta/hinin category; and oppression both within classes and between classes. The oppression of women, who are limited to roles as wives or prostitutes, is due to the Confucian ethics of the ruling class and the patriarchal codes of Edo society. But multiple forms of oppression are also suffered by the male merchant-class protagonists: unsuccessful (and therefore low class) merchants are repressed by the ruling class discourse but also by members of their own class, the villains who interfere with their affairs using their greater wealth, as well as by the patriarchal super-ego figures who thwart their desires by reminding them of their principles. These various types of oppression are present in Chikamatsu's shinjū genre, and form the different dramatic tensions and complications in the play. 


\subsection{The Complexity of Morality in the Edo period}

So far, we have seen various conflicts caused by the social structure of the Edo period. Now I will discuss the internal ambivalence of the protagonist. Scholars have seen the moral ambivalence of protagonists as the ultimate theme of shinjū plays. They suffer from the internal tension between giri (social obligation) and ninjō (human passion): in other words, they are torn between their public duties and their private desires. According to Suwa, this giri-ninjō conflict, which Tsubouchi Shōyō first suggested in early Meiji period, has become a formula for understanding not just Chikamatsu's plays, but Edo literature as a whole (Suwa, 1977, p.111-112). However, merchant class ethics have a complicated structure, as we have seen. We must now examine the ways in which giri and ninjō in shinjū plays are portrayed in relation to Edo social structures.

First, we need to understand the significance of giri in Chikamatsu's sewamono genre. According to Minamoto Ryōen (1969, pp.27-34), the definition of giri varies among scholars, but in general it describes the feeling that arises in the following situation: when one receives a favor from a non-related member of one's community, one feels obliged to return the favor in some way, and failing to do so may result in being excluded from the community. However, this simple definition does not adequately cover the various elements of giri in the intricate human relationships within Shinjū Ten no Amijima.

Considering the idea of giri in relation to the social structure provides a different focus through which we can interpret the play. Sakurai Shōjirō (1961, pp.255-256) has conducted intensive research into the ethics of the farmer, merchant, and military classes. He argues that the concept of giri appeared frequently during the feudal period and was established in the merchant discourse, whereas the concept of on-hōko was shaped by the military class in the Edo period. He defines giri as a social awareness of contract and gift-giving between individuals who are socially equal. On-hōko, however, is based on a social awareness of contract and gift-giving between individuals who are not socially equal (Note 3 ). In other words, giri derives from the equal communal awareness of the merchants, while on derives from the difference of status in the military class. The notions of honesty and sincerity in the merchant principle discussed above are not chiefly derived from conscience, but rather from the necessity to sustain business relationships.

There are numerous textual examples that show the equal relational feature of giri in the merchant class. In Nebiki no Kadomatsu, for example, protagonist Yojihei feels a strong sense of giri toward his brother-in-law Yohei. Yojihei is greatly helped by his brother-in-law when he and Hikosuke are rivals for the same courtesan. Therefore, when Yohei injures Hikosuke in a fight, Yojihei decides to take the punishment for Yohei since he feels "otoko no giri" (giri between two males) towards Hikosuke, and Yojihei wants to protect Yohei, who fights on his behalf. This friendship, then, is based on the equal relationship between the brothers-in-law (Suwa, 1977, p.114).

In Shinjū Ten no Amijima, meanwhile, giri is based on an equal relationship between two women. Jihei feels mixed emotions of guilt and gratitude when his wife Osan helps him to buy out Koharu's contract. As we have seen in the previous section, a wife did not have an equal position in relation to her husband: their relationship had elements of the master-servant relationship. While Jihei feels grateful to Osan, she tells him she does not deserve this gratitude, and she would be glad to rip the nails from her fingers and toes "to do anything which might serve" her husband without reward (Keene, 1961, p.194). This makes her the ideal figure of the wife, and her one-sided devotion makes Jihei feel guilty. The relationship between Osan and Koharu, on the other hand, is based on their equality. When she writes to ask Koharu to save Jihei's life, Osan fully trusts Koharu despite the fact that she is both a prostitute and a rival. When Koharu swears to save Jihei, Osan decides to help her because she feels "onna dōshi no giri" (giri between women). This means that Koharu cannot die with Jihei since she cannot break her promise to Osan. When Jihei and Koharu decide to commit double suicide, Koharu shows what she thinks of this giri:

Osan will think then that I treated as mere scrap paper the letter I sent promising her, when she asked me not to kill you, that I would not, and vowing to break all relations. She will be sure that I lured her precious husband into a lover's suicide. She will despise me as a one night-prostitute, a false woman with no sense of decency. I fear her contempt more than the slander of a thousand or ten thousand strangers. (Keene, 1961, p.204)

It is clear that Koharu believes her giri is based on an equal relationship with Osan. Koharu is very grateful that Osan had trusted her and confessed her true heart in spite of her status as a prostitute.

This example demonstrates that giri is not always attended by connotations of reluctant obligation. Koharu may be afraid of Osan's contempt, since they made a contract as independent individuals, but there is also a strong element of sincerity: Osan and Koharu have an equal relationship and they trust each other, and thus giri carries with it the element of a positive social contract. The ambivalence arises when the protagonists try to be honest both to this honorable giri contract and to the accomplishment of love. 
However, when the relationship is not equal, giri in the merchant class becomes on-hōko. On in the military class is enacted in a situation where the superior gives a reward such as land to his inferiors, who are then obliged to serve the master in recompense (Sakurai, 1961, p.64). In the merchant class this is reflected in differences in individual status or age. As we have seen, the conflict between the patriarchal figure and the unsuccessful merchant lies in whether or not the proper merchant principles are being observed. In ethical terms we can understand this as a conflict of the observance of on.

In Sonezaki Shinjū, for instance, when protagonists Tokubei and Ohatsu are about to commit double suicide, Tokubei mentions his failure to observe the ethics of on:

My parents died when I was a boy, and I grew up thanks to the efforts of my uncle, who was my master. It disgraces me to die without repaying his kindness. Instead I shall cause him trouble which will last even after my death. Please forgive my sins (Keene, 1961, p.55).

Ohatsu, meanwhile, cries because her suicide will disgrace her parents and siblings. Tokubei and Ohatsu still show the proper respect to the patriarchal figures who have caused the tragedy, and they do not blame them: Tokubei obeys his master, who has forced Tokubei to marry, and Ohatsu cares for her parents, who sold her to the pleasure quarters. Despite the fact that their actions place them in opposition to these figures, they nevertheless feel guilt for failing to fulfill their obligations to them. The concept of on, then, brings about internal moral conflict.

All of the protagonists are employed by successful merchants or supervisors, or they take over businesses from their parents. In return they must work hard. If the inferior insists on independence with regard to personal matters such as love, the superior must intervene in order to maintain superiority in the on-hōko relationship. When Jihei's aunt, who is also his mother-in-law, visits him in order to make sure that he terminates his relationship with Koharu, she constantly reminds him of his moral obligation to his family:

(To Jihei) Your father was my brother. When the poor man was on his deathbed, he lifted his head from the pillow and begged me to look after you, as my son-in-law and nephew. I've never forgotten those last words, but your perversity has made a mockery of his request! ...(To Osan) I'm sure that Jihei will settle down and his business will improve, now that he's in this frame of mind. It's been entirely for his sake and for love of the grandchildren that we've intervened. (Keene, 1961, pp.189-190)

The aunt stresses the ways in which Jihei is ignoring his moral obligations to his family. He is not a wholly independent person: he has a duty to serve his family and his family's business, as he is indebted to them for his current position. His aunt says that his family is intervening in his affair because they believe that doing so is in his best interests.

This is similar to the master-servant relationship in the military class: one must repay the kindness of one's superiors by serving them well. In this case, giri becomes on: a social obligation. The internal conflict arises when the protagonists desire to achieve full independence as individuals by escaping the notion of on .

Thus, within merchant-class ethics the concept of giri works horizontally and the concept of on works vertically. However, as Moriyama observes, in Chikamatsu's sewamono genre, we discover that the merchant has yet another form of ethics, called ichibun (Moriyama, 1960, p.211). Ichibun is well illustrated in the conflict between the protagonist and the villain. As we have seen, there exists a conflict between villains and unsuccessful merchants. Villains, who do not observe mainstream merchant ethics, interfere in the protagonists' love by wielding economic power and employing deceitful devices. Yet, as Moriyama points out, the villains' role is not simply characterized by small disturbances in the play, even though they are described in a rather stereotypical way. The conflict between villains and unsuccessful merchants is ethically related to the concept of ichibun (Moriyama, 1960, pp.214-216).

According to Moriyama, ichibun is the sense of individual dignity which is not related to the master-servant relationship. It is also different from the idea of lineage which is passed on by the family name $(n a)$. And, while it is similar to giri in terms of its communal aspect, ichibun deals more directly with individual honor and dignity. The lineage of $n a$ was supported by the military class and its rigid sense of hierarchy, but ichibun is established by the people within a community without master-servant status difference. Therefore, like giri, ichibun is part of merchant class discourse. Ichibun is, however, not interchangeable with giri. Both are social concepts established in the merchant community. But Ichibun is personal trust or reputation in relation to the community: the relationship between an individual and her or his community. Giri, on the other hand, is the ethics between individuals in a community. Consequently, giri is characterized by very complex relationships between people, whereas ichibun deals with an individual's own private concerns (Moriyama, 1960, pp.216-218). 
How is the ethical concept of ichibun described in Shinjü Ten no Amijima in the relationship between the villain and the protagonist? Moriyama (1960, pp.214) argues that the villain's role in the play is not merely to interfere with the protagonist's love, but is in fact to destroy his ichibun. The villain attacks the individual honor of the protagonist, whereas the patriarchal figure attempts to remind him of his social duty. In Sonezaki Shinjū, the ultimate cause of the double suicide is the fact that Kuheiji has destroyed Tokubei's ichibun. Because Kuheiji does not return the money he borrowed from Tokubei, Tokubei cannot return the money to his master. Moreover, Kuheiji imputes a crime to Tokubei by fabricating the story that Tokubei has stolen Kuheiji's chop and created a false contract. Kuheiji humiliates Tokubei and destroys his reputation as an honest merchant in front of many townspeople. He is angry: not only because without the money he cannot escape from his arranged marriage, but also because he feels humiliated. Kuheiji trumpets Tokubei's blunder in the pleasure quarters:

Tokubei ... found a seal I'd lost and tried to cheat me out of two Kamme in silver with a forged note. The facts were too much for him, and he finally met with some unpleasantness from which he was lucky to escape to alive. His reputation has been ruined. (Keene, 1961, p.49)

In this passage, it is clear that Kuheiji is deliberately trying to damage Tokubei's ichibun in the community.

To lose one's ichibun in the merchant society would have been very serious, since ichibun manifests itself not only in one's reputation as a member of the community, but also in one's honesty and righteousness as an individual. Therefore, Tokubei decides to recuperate his ichibun through death, saying, "before three days have passes, I, Tokubei, will make amends by showing all Osaka the purity at the bottom of my heart" (Keene, 1961, p.47).

Similarly, in Shinjü Ten no Amijima, Jihei tearfully confesses to Osan that he feels humiliated by Tahei. While it is obvious that Jihei is also upset about Koharu, he fears that Tahei will dishonor him by telling everyone that his business is failing and that he is pressed for money. Jihei is afraid of "contemptuous stares from the wholesalers" (Torigoe, 1975b, p.488) (Note 4). Osan tells Jihei, "my husband's reputation concerns me more. Ransom Koharu. Save her. Assert your honor before Tahei” (Torigoe, 1975b, p.193) (Note 5). Thus, ichibun is a sense of individual pride of which all merchants - even those of the lowest status - are strongly aware. Once this sense of pride is damaged, it is very difficult for the merchant to maintain his reputation and honor and to conduct business in the community. Indeed, the idea of ichibun is highly valued and must be recovered at all costs - even by death.

The protagonists, therefore, are plagued by three different internal ethical conflicts: giri, which works horizontally in the merchant society; on, which works vertically; and ichibun, which operates privately. All of these conflicts are ultimately responsible for the protagonists' tragic plight. Giri causes emotional strife when the protagonists attempt to adhere to contracts with their equals and to accomplish love. On creates a sense of guilt when the protagonists desire full independence as individuals - independence, that is, from the patriarchal figures who worry about their family traditions and duty. And ichibun brings about severe instances of humiliation when it is destroyed by villains who do not observe merchant principles and ignore the concepts of giri and on.

It is therefore not enough to understand Chikamatsu's masterpiece Shinjū Ten no Amijima simply in terms of the conflict between giri and ninjō. In fact, according to Minamoto, except in one instance, Chikamatsu himself did not use the word ninjō. Instead, he used the word nasake or $j \bar{o}$, which originally means sympathy rather than uncontrollable passion. For Chikamatsu, the word $j \bar{o}$ is the basic concept of humanism. In Satsuma Uta (The Song of Satsuma), for example, he says "a human being is the flower of sympathy." In Chikamatsu's work $j \bar{o}$ is neither strictly moralistic nor anti-moralistic: it is beyond morality, and relates to affectionate human emotion (Minamoto, 1969, p.18).

Accordingly, adherence to giri, which shows positive emotional flow and one's humanity, does not necessarily conflict with the concept of $j \bar{o}$. In Shinjū Ten no Amijima, we see more complex internal conflicts: Osan feels giri towards Koharu, but on towards Jihei, whom she helps to recover his ichibun. Koharu feels giri towards Osan and on towards her parents, but $j \bar{o}$ towards Jihei. Jihei feels on towards his family and Osan, and his loss of ichibun complicates his internal conflict, yet he cannot give up his love. Shinjū Ten no Amijima thus reflects three different ethical notions in the merchant class discourse, as well as the spontaneous feeling of $j \bar{o}$. The double suicide is not a triumph of sympathy and love against social obligation or oppression: it is beyond such a reductive and stereotypical dichotomy. Jihei and Koharu die because they cannot fulfill either $j \bar{o}$ or giri. The bond between Osan and Koharu is equal to the love between Jihei and Koharu. These two notions of $j \bar{o}$ and giri are inseparable.

Shinjū Ten no Amijima illustrates that $j \bar{o}$ and giri were essential concepts for townspeople in Chikamatsu's age. Jō and giri became one thing in the merchant community, where principles and ethics were indispensable since the merchants needed to establish their own discourse distinct from that of the ruling class. By showing this merchant spirit, it was possible for the merchant class to challenge the ruling class which tried to suppress any possibility of individuality and independence within the merchant class. 


\section{Conclusion}

In Chikamatsu's sewamono genre, we discover very complex social and ethical structures which derive from differences of status within the social structure. It is abundantly clear that jōruri plays depict the merchants' indirect defiance of the military class, but the people who fell below the four-class structure-like eta/hinin —also suffer from their contradictory roles in society. Both merchants and eta/hinin were indispensable to the ruling class, yet their roles were despised and they were excluded from political power. The social structure was inherently unequal, but at the same time there was also imparity and conflict within social classes. For example, the Confucian ethics of the ruling class and the androcentric patriarchal society created an unnatural division of female roles; the housewife was reduced to the status of domestic and private property, while the courtesan figured as erotic and always publicly available. Similarly, the male protagonists in Chikamatsu's plays are unsuccessful lower-status merchants, who occupy vastly different social positions to the patriarchs and the villains. The protagonists are oppressed by their superiors within their own class, who remind them of their merchant principles. Likewise, they are victimized by the villains, who intervene in their love affairs using their superior economic power.

The ethics of the merchant class were therefore complicated. The concept of giri was established in merchant-class discourse: fairness and honesty were indispensable in business. Giri is a social contract between independent, equal individuals in the same community: the positive, spontaneous feeling of obligation of one person toward another. However, giri induces internal conflict when the protagonists attempt to follow both this contract and to find love.

The conflict between the protagonists and the patriarchal figures evolves into the observance of on. Unlike giri, on is the ethical concept that operates when two people are not equal. On, therefore, exerts enormous pressure on the protagonists, who are attempting to ignore their social duty to serve the patriarch and to be fully independent. Finally, the conflict between the protagonists and the villains is ethically related to the concept of ichibun. Ichibun is one's individual pride and reputation in the community, and it was vitally important to all merchants as the foundation of their business in a small community. The villains destroy the protagonists' ichibun, bringing them to humiliation and even death.

Chikamatsu's masterpiece Shinjū Ten no Amijima contains all of these social and ethical conflicts: all the characters are bound in conflicting and overlapping obligations of giri, on, jō and ichibun. The death of Jihei and Koharu moves beyond the simple dichotomy between giri and ninjō: Jihei and Koharu die for both giri and jō. Koharu cannot break her promise to Osan; Osan cannot betray Koharu's confidence and courage. Theirs is a relationship based on humanity. Jihei and Koharu love each other and Jihei respects Koharu's request, hoping they can be together in the next world.

Shinjū Ten no Amijima succeeds in depicting the rich humanity of the merchant class by illustrating its ethics of obligation, human relations, sympathy and pride. In this sense, despite its tragic ending, we can conclude that Shinjü Ten no Amijima challenges the ruling class discourse which attempts to oppress the power and individuality of the merchants by revealing the original humanistic discourse of the merchant class.

\section{Notes}

Note 1. Jöruri is a "style of singing in puppet theater that developed from 1600; or [a] general term for the puppet theater." See C. Andrew Gerstle, Circle of Fantasy: Convention in the Plays of Chikamatsu (Cambridge: Harvard Univ. Press, 1986), 212.

Note 2. There were four classes in this period, based on Chinese Confucian ideas: the warrior class (samurai) at the top, followed by the farmers, then the artisans, and finally the merchants. In fact, however, there were two additional categories: the nobility, who were above the class system, and the eta and hinin, who were below it. The system was rigid and fixed: one could not rise above one's station (one could, though, fall below it, as did Chikamatsu himself).

Note 3. Potlatch is the idea that "ceremonial distribution of property and gifts to affirm or reaffirm social status." Encyclopedia Britannica $14^{\text {th }}$ ed., s.v. "potlatch."

Note 4. My translation.

Note 5. My translation.

\section{References}

de Bary, B. (1993, Spring). Not Another Double Suicide: Gender, National Identity, and Repetition in Shinoda Masahiro's Shinjū Ten no Amijima. Iris, 16, 57-86. 
Gerstle, C. A. (1986). Circle of Fantasy: Convention in the Plays of Chikamatsu. Cambridge: Harvard Univ. Press.

Heine, S. (1994, May). Tragedy and Salvation in the Floating World: Chikamatsu's Double Suicide Drama as Millenarian Discourse. The Journal of Asian Studies, 53(2), 367-397. http://dx.doi.org/10.2307/2059839

Keene, D. (1961). Four Major Plays of Chikamatsu. New York: Columbia Univ. Press.

Minamoto, R. (1969). Giri to Ninjō: Nihonteki Shinjō no Ichikōsatsu. Tokyo: Chūōkōronsha.

Moriyama, S. (1960). Hōken Shomin Bungaku no Kenkyū. Kyoto: San'ichi Shobō.

Nakata, Y. (1955, January). Chikamatsu to Chōnin no Sekai: Chōnin Rinri no Mondai wo Chūshin ni. Kokugo to Kokubungaku, 31-45.

Saeki, J. (1987). Yūjo no Bunkashi: Hare no Onna tachi. Tokyo: Chūōkōronsha.

Sakurai, S. (1961). On to Giri: Shakaigakuteki Kenkyū. Tokyo: Asahisha.

Shinoda, M. (1971). Kurogo no Hassō. Shinjū Ten no Amijima. Tokyo: Kamensha.

Shively, D. H. (1955). Bakufu versus Kabuki, Harvard Journal of Asiatic Studies, 18(3/4), 326-356. http://dx.doi.org/10.2307/2718437

Suwa, H. (1974). Chikamatsu Sewa Jōruri no Kenkyū. Tokyo: Kasama Shobō.

Suwa, H. (1977). Shinjū - Sono Shi to Shinjitsu. Tokyo: Mainichi Shinbunsha.

Torigoe, B. (ed.) (1975a). Chikamatsu Monzaemon Shū I. Nihon Koten Bungaku Zenshū series, 43. Tokyo: Shōgakukan.

Torigoe, B. (ed.) (1975b). Chikamatsu Monzaemon Shū II. Nihon Koten Bungaku Zenshū series, 44. Tokyo: Shōgakukan.

\section{Copyrights}

Copyright for this article is retained by the author(s), with first publication rights granted to the journal.

This is an open-access article distributed under the terms and conditions of the Creative Commons Attribution license (http://creativecommons.org/licenses/by/3.0/). 